\title{
Occurrence and risk factors associated with canine leptospirosis
}

\author{
Kikuti M (1), Langoni H (1), Nobrega DN (1), Corrêa APFL (1), Ullmann LS (1)
}

(1) Department of Veterinary Hygiene and Public Health, School of Veterinary Medicine and Animal Husbandry, São Paulo State University (UNESP - Univ Estadual Paulista), Botucatu, São Paulo State, Brazil.

\begin{abstract}
Leptospirosis is a globally distributed emerging zoonosis. Dogs are commonly affected and although other serovars can cause canine leptospirosis, Leptospira interrogans serovar Canicola is primary found in these animals. A retrospective study was conducted using a database of 1195 dogs tested for Leptospira infection from 2003 to 2010 at the Laboratory of Zoonosis Diagnosis at the Veterinary Hospital of São Paulo State University (UNESP) in Botucatu, São Paulo state, Brazil. The seroprevalence of infected dogs was 20.08\% (240/1195), and the most prevalent serovars were Canicola (6.7\%), Copenhageni (5.0\%), Icterohaemorrhagiae (2.9\%), Autumnalis (2.9\%), Pyrogenes (2.8\%), Pomona (2.0\%), Hardjo (2.0\%), Australis (1.8\%), Bratislava (1.6\%), Cynopteri (1.4\%), Grippotyphosa (1.3\%) and Djasiman (1.0\%). By univariate analysis, the variables age and breed were not statistically related to the infection, while gender and season were. The effects of gender were also noticeable related to serovars Australis, Canicola and Hardjo. In multivariate analysis, the level of significance ( $p$-value) of season was suppressed by gender, indicating possible collinearity between those two variables.
\end{abstract}

Key words: Leptospira spp., dog, serology, epidemiology.

Leptospirosis is a worldwide spread emerging zoonosis due to its increasing incidence in developed and developing countries. However, higher prevalence rates are found in tropical countries $(1,2)$. It is caused by spirochetes of the Leptospira genus, divided into pathogenic and saprophytic species with more than 200 pathogenic and 60 saprophytic serovars (1).

Its transmission occurs through direct contact with urine infected with leptospires or indirect contact with contaminated moist environment (1, 3). Reservoirs are wild or domestic animals such as rodents, cattle or dogs. The latter is considered a dead-end host due to infrequent transmission to humans $(4,5)$.

Although dogs are considered reservoirs of Leptospira interrogans serovar Canicola, canine leptospirosis is reported to be caused by other serovars as well $(3,6,7)$. Canine leptospirosis seroprevalence ranges from $1.9 \%$ in shelter animals to $35 \%$ in serological surveys $(6,8,9)$.

In humans, leptospirosis risk factors are connected with occupational, recreational, and sportive activities, including ecotourism, whereas environmental aspects must also be considered (10-12). Unlike the human form of the infection, canine leptospirosis risk factors are not completely known and further studies are required. Age, breed and gender do not appear to represent risk factors for canine leptospirosis, though environmental characteristics such as increase of rainfall and temperature are proven to be part of the seasonal characteristic of the disease $(3,6,13)$. 
The present work is a retrospective study conducted using a database of 1195 dogs tested for leptospirosis infection, from November 2003 to September 2010, at the Laboratory of Zoonosis Diagnosis of the Veterinary Hospital of São Paulo State University (UNESP) in Botucatu, SP, Brazil. Animals were from several cities of São Paulo state as well as other Brazilian states. Data on gender (male or female), age (less than one year or older than one year), breed (mixed-breed or purebred) and city of origin were collected. Serum was obtained after centrifuging at $400 \mathrm{~g}$ for ten minutes, and stored at $-20^{\circ} \mathrm{C}$ until use.

Diagnosis was performed using the goldstandard serological microscopic agglutination test (MAT) using live antigens for antibody detection. Twelve pathogenic serovars were employed: Leptosipra interrogans serovars Australis, Bratislava, Autumnalis, Canicola, Djasiman, Copenhageni, Icterohaemorraghiae, Pomona, Pyrogenes and Hardjo, and Leptospira kirshneri serovars Cynopteri and Grippotyphosa. Samples were considered reagent when titers were equal to or greater than 100 . When an animal presented detectable antibodies against more than one serovar, all reactive serovars were considered to determine the occurrence of the infection. For risk factor analysis, the animal was considered positive, regardless of number of reactive serovars. Differences in leptospirosis rates according to different variables were determined by the chi-squared test.

Logistic regression was performed using explanatory variables with significant results in the chi-squared test. Odds ratios (OR) were estimated with 95\% confidence intervals (upper bound - UB95\% and lower bound - LB95\%).

The occurrence of anti-Leptospira spp. antibodies in dogs was $20.08 \%(240 / 1195)$ and serovars Canicola (6.7\%), Copenhageni $(5.0 \%)$, Icterohaemorrhagiae (2.9\%), Autumnalis $(2.9 \%)$, Pyrogenes (2.8\%), Pomona (2.0\%), Hardjo (2.0\%), Australis (1.8\%), Bratislava (1.6\%), Cynopteri (1.4\%), Grippotyphosa (1.3\%) and Djasiman (1.0\%) were found.

Concerning seasons, the higher incidence of leptospirosis was observed in autumn (25.5\%), followed by winter (19.4\%), summer (18.5\%) and spring (17.6\%). The occurrence of the infection, regarding month of its onset, was distributed as follows: April (17.9\%), July (12.9\%), November (10.8\%), March (10.0\%), August (7.9\%), February
(7.5\%), May (7.1\%), January (6.3\%), June (6.3\%), October (5.8\%), September (5.4\%) and December (2.1\%). Regarding the age of animals, $24.2 \%$ of them were less than one year old and $21.3 \%$ of older animals were seropositive. Mixed-breed and purebred animals tested positive, respectively, in 21.6 and $21.2 \%$ of the samples. Age and breed were not statistically related to higher rates of leptospirosis. However, male animals $(25.4 \%$ versus $17.6 \%$ of females) and dry season $(22.7 \%$ versus $17.4 \%$ ofwet season) were characteristics connected with higher rates of leptospirosis antibodies (Table 1). The multivariate analysis confirmed that only gender had a significant contribution to the model $\left(\mathrm{OR}_{\text {male } \mathrm{x} \text { female }}=1.692\right.$, UP95\% $=2.475$, LB95\% $=1.157$ ) (Table 2). Collinearity was detected between gender and season using the correlation matrix. The variable with higher contribution to the model (gender) was kept in order to access its effect.

The observed influence of gender was probably due to the serovars Australis $\left(\mathrm{OR}_{\text {male x female }}=2.807\right.$, UB95\% $=8.629$, LB95\% $=0.907$ ), Canicola $\left(\mathrm{OR}_{\text {male x female }}=4.078, \mathrm{UB} 95 \%=1.869, \mathrm{LB} 95 \%=\right.$ $8.898)$ and Hardjo $\left(\mathrm{OR}_{\text {male } x \text { female }}=3.937, \mathrm{UB} 95 \%=\right.$ 11.747 , LB95\% $=1.319)$.

The seroprevalence of anti-Leptospira spp. antibodies in dogs reported in other studies in Brazil ranges from 2.66 to $85 \%$ in serological surveys (14-17). In the present study, the observed occurrence was $20.08 \%$, which corroborates previous studies.

The present work found that predominant serovars of Leptospira spp. were Canicola (6.7\%), Copenhageni (5.0\%), Icterohaemorrhagiae (2.9\%) and Autumnalis (2.9\%), which agrees with several previous studies around the world that show that predominant serovars belong to serogroups Icterohaemorrhagiae and Canicola (14).

Regarding risk factors, several studies reported age as a risk factor, with dogs older than 12 months being associated with higher occurrence $(14,16)$. In the present study, age did not represent a risk factor, in conformity with another study conducted in Thailand (6).

In the current study, breed was not statistically associated with the infection, differing from another study in which mixed-breed was considered to be a risk factor (14). Male dogs showed more antibodies against leptospirosis, specially related to serovars Australis, Canicola 
Table 1. Absolute frequency and relative frequency (\%) of seropositivity to leptospirosis according to age, breed, season and gender as well as values of chi-squared test $\left(X^{2}\right)$, its significance in $p$ (two-tailed) degrees of freedom, and odds ratio with its upper (UB95\%) and lower (LB95\%) bounds of 95\% confidence intervals

\begin{tabular}{|c|c|c|c|c|c|c|c|c|c|}
\hline & \multicolumn{2}{|c|}{ Serology } & \multirow{2}{*}{$\%$} & \multirow{2}{*}{$x^{2}$} & \multirow{2}{*}{ DF } & \multirow{2}{*}{$p$} & \multirow{2}{*}{ UB (95\%) } & \multirow{2}{*}{ OR } & \multirow{2}{*}{$\begin{array}{c}\text { LB } \\
(95 \%)\end{array}$} \\
\hline & Reactive & Non-reactive & & & & & & & \\
\hline \multicolumn{10}{|l|}{ Age } \\
\hline$<1$ year & $8(24.2 \%)$ & 25 (75.8\%) & 33 (4.4\%) & \multirow{2}{*}{0.166} & \multirow{2}{*}{1} & \multirow{2}{*}{0.684} & \multirow{2}{*}{-} & \multirow{2}{*}{-} & \multirow{2}{*}{-} \\
\hline$>1$ year & $154(21.3 \%)$ & $570(78.7 \%)$ & 724 (95.6\%) & & & & & & \\
\hline \multicolumn{10}{|l|}{ Breed } \\
\hline MB & 77 (21.6\%) & 279 (78.4\%) & 356 (44.8\%) & \multirow{2}{*}{0.018} & \multirow{2}{*}{1} & \multirow{2}{*}{0.892} & \multirow{2}{*}{-} & \multirow{2}{*}{-} & \multirow{2}{*}{-} \\
\hline PB & $93(21.2 \%)$ & 345 (78.8\%) & 438 (55.2\%) & & & & & & \\
\hline \multicolumn{10}{|l|}{ Season } \\
\hline Dry & $138(22.7 \%)$ & 471 (77.3\%) & 609 (51.0\%) & \multirow{2}{*}{5.136} & \multirow{2}{*}{1} & \multirow{2}{*}{0.023} & \multirow{2}{*}{1.045} & \multirow{2}{*}{1.390} & \multirow{2}{*}{1.850} \\
\hline Wet & $102(17.4 \%)$ & $484(82.6 \%)$ & $586(49.0 \%)$ & & & & & & \\
\hline \multicolumn{10}{|l|}{ Gender } \\
\hline Female & 61 (17.6\%) & 286 (82.4\%) & 347 (45.9\%) & \multirow{2}{*}{6.778} & \multirow{2}{*}{1} & \multirow{2}{*}{0.009} & \multirow{2}{*}{0.439} & \multirow{2}{*}{0.626} & \multirow{2}{*}{0.892} \\
\hline Male & $104(25.4 \%)$ & $305(74.6 \%)$ & $409(54.1 \%)$ & & & & & & \\
\hline Total & $165(21.8 \%)$ & $591(78.2 \%)$ & 756 (100.0\%) & & & & & & \\
\hline
\end{tabular}

MB: mixed-breed; PB: purebred; DF: degree of freedom; OR: odds ratio; $p$-values followed by * indicate significance considering a $=0.05$ (one-tailed)

Table 2. Values of $p$ of predictor variables adopted in the logistic regression model, values of $B$ and $\operatorname{Exp}(B)$ as well as their upper (UB) and lower (LB) bounds of $95 \%$ confidence interval and R2 values of the model (Nagelkerke; Cox \& Snell)

\begin{tabular}{c|c|c|c|c|c}
\hline Variable & $\mathbf{p}$ & $\mathbf{B}$ & $\operatorname{Exp}(\mathbf{B})$ & LB & UB \\
\hline Age & 0.662 & - & - & - & - \\
\hline Gender & 0.007 & 0.526 & 1.692 & 1.157 & 2.475 \\
\hline Season & 0.464 & - & - & - & - \\
\hline Breed & 0.690 & - & - & - & - \\
\hline Gender-season $^{*}$ & 0.906 & - & - & - & - \\
\hline
\end{tabular}

*Interaction between gender and season.

$\mathrm{R}^{2}\left(\right.$ Cox \& Snell) $=0.011 ; \mathrm{R}^{2}$ (Nagelkerke) $=0.017 ;$

and Hardjo. Gender is a controversial variable since some studies report it as risk factors while others do not $(6,16)$. Wet or dry season did not interfere in the occurrence of anti-Leptospira antibodies.

Based on the present findings, it is possible to attribute some importance to the serovars Canicola, Copenhageni, Icterohaemorrhagiae and Autumnalis. Therefore, the predominant serovars belong to the Icterohaemorrhagiae and Canicola serogroups. Such results reinforce the impact of epidemiologic studies for a better understanding of leptospirosis in dogs.

\section{COPYRIGHT}

(c) CEVAP 2012

\section{SUBMISSION STATUS}

Received: July 28, 2011.

Accepted: October 21, 2011.

Abstract published online: October 26, 2011.

Full paper published online: February 28, 2012.

\section{CONFLICTS OF INTEREST}

The authors declare no conflicts of interest. 


\section{CORRESPONDENCE TO}

Helio Langoni, Departamento de Higiene Veterinária e Saúde Pública, Faculdade de Medicina Veterinária e Zootecnia, UNESP, Distrito de Rubião Júnior, s/n, Botucatu, SP, 18618-970, Brasil. Phone: +55 143811 6270. Fax: 55143811 6075. Email: hlangoni@fmvz.unesp.br.

\section{REFERENCES}

1. Adler B, de la Peña Moctezuma A. Leptospira and leptospirosis. Vet Microbiol. 2010;140(3-4):287-96.

2. Slack A. Leptospirosis. Aust Fam Physician. 2010;39(7):495-8.

3. Alton GD, Berke O, Reid-Smith R, Ojkic D, Prescott JF. Increase in seroprevalence of canine leptospirosis and its risk factors, Ontario 1998-2006. Can J Vet Res. 2009;73(3):167-75.

4. Prescott J. Canine leptospirosis in Canada: a veterinarian's perspective. Can Med Assoc J. 2008;178(4):397-8.

5. Reis RB, Ribeiro GS, Felzemburgh RDM, Santana FS, Mohr S, Melendez AX, et al. Impact of environment and social gradient on Leptospira infection in urban slums. PLoS Negl Trop Dis. 2008;2(4):e288.

6. Meeyam T, Tablerk P, Petchanok B, Pichpol D, Padungtod P. Seroprevalence and risk factors associated with leptospirosis in dogs. Southeast Asian J Trop Med Public Health. 2006;37(1):148-53.

7. Suepaul SM, Carrington CVF, Campbell M, Borde G, Adesiyun AA. Serovars of Leptospira isolated from dogs and rodents. Epidemiol Infect. 2010;138(7):105970 .

8. Davis MA, Evermann JF, Petersen CR, Vander Schalie J, Besser TE, Huckabee J, et al. Serological survey for antibodies to Leptospira in dogs and raccoons in Washington State. Zoonoses Public Health. 2008;55(810):436-42 .

9. Zwijnenberg RJG, Smythe LD, Symonds ML, Dohnt MF, Toribio JA. Cross-sectional study of canine leptospirosis in animal shelter populations in mainland Australia. Aust Vet J. 2008;86(8):317-23.
10. Langoni H. Leptospirose: Aspectos de saúde animal e de saúde pública. Rev Educ Cont CRMV-SP. 1999;2(2):52-8.

11. Monahan AM, Miller IS, Nally JE. Leptospirosis: risks during recreational activities. J Appl Microbiol. 2009;107(3):707-16.

12. Dias JP, Teixeira MG, Costa MC, Mendes CM, Guimarães P, Reis MG, et al. Factors associated with Leptospira sp. infection in a large urban Center in Northeastern Brazil. Rev Soc Bras Med Trop. 2007;40(5):499-504.

13. Hazart G, Hugonnard M, Kodjo A, Groud K, GoyThollot I. La leptospirose canine en France: etude rétrospective de 37 cas. Prat Med Chirur Anim Compagnie. 2010;45(2):59-64.

14. Batista CSA, Alves CJ, Azevedo SS, Vasconcellos SA, Morais ZM, Clementino IJ, et al. Soroprevalência e fatores de risco para leptospirose em cães de Campina Grande, Paraíba. Arq Bras Med Vet Zootec. 2005;57(2):179-85.

15. ModoloJR, Langoni H, PadovaniCR, Shimabukuro FH, Mendonça AO, et al. Investigação soroepidemiológica de leptospirose canina na área territorial urbana de Botucatu, São Paulo, Brasil. Braz J Vet Res Anim Sci. 2006;43(5):598-604.

16. Aguiar DM, Cavalcante GT, Marvulo MFV, Silva JCR, Pinter A, Vasconcellos SA, et al. Fatores de risco associados à ocorrência de anticorpos anti-Leprospira spp. em cães do município de Monte Negro, Rondônia, Amazônia Ocidental Brasileira. Arq Bras Med Vet Zootec. 2007;59(1):70-6.

17. Viegas SAR, Tavares CHT; Oliveira EMD, Dias AR, Mendonça FF, de Santos MFP. Investigação sorológica para leptospirose em cães errantes na cidade de Salvador - Bahia. Rev Bras Saúde Prod Anim. 2001;2(1):21-30. 